\title{
Aa. Vv., «Questes. Bulletin des jeunes chercheurs médiévistes», 17
}

Maria Colombo Timelli et [mariagrazia ricci]

\section{(2) OpenEdition}

\section{Journals}

Édition électronique

URL : http://journals.openedition.org/studifrancesi/6213

DOI : 10.4000/studifrancesi.6213

ISSN : 2421-5856

Éditeur

Rosenberg \& Sellier

\section{Édition imprimée}

Date de publication : 1 novembre 2010

Pagination : 534

ISSN : 0039-2944

\section{Référence électronique}

Maria Colombo Timelli et [mariagrazia ricci], «Aa. Vv., «Questes. Bulletin des jeunes chercheurs médiévistes», 17 », Studi Francesi [En ligne], 162 (LIV | III) | 2010, mis en ligne le 30 novembre 2015, consulté le 13 janvier 2021. URL : http://journals.openedition.org/studifrancesi/6213 ; DOI : https:// doi.org/10.4000/studifrancesi.6213

Ce document a été généré automatiquement le 13 janvier 2021.

\section{cc) (†) $\ominus$}

Studi Francesi è distribuita con Licenza Creative Commons Attribuzione - Non commerciale - Non opere derivate 4.0 Internazionale. 


\title{
Aa. Vv., «Questes. Bulletin des jeunes chercheurs médiévistes», 17
}

\author{
Maria Colombo Timelli et [mariagrazia ricci]
}

\section{RÉFÉRENCE}

«Questes. Bulletin des jeunes chercheurs médiévistes», 17, 2009, 128 pp.

1 Les études concernant le Moyen Âge sont signalées dans la section précédente.

2 Julien ABED (Femmes Illustres et Illustres reines: la communication politique au tournant des $\mathrm{XV}$ e et $X V I^{e}$ siècles, pp.52-69) traite du "genre du recueil encomiastique consacré exclusivement aux femmes" (p. 52), en se concentrant en particulier sur des œuvres ayant comme dédicataires des reines et princesses contemporaines. L'A. montre comment ces dédicaces développent la thématique des femmes Illustres au-delà du texte fictionnel: la louange des héroïnes anciennes sert aussi pour illustrer les vertus des dames d'aujourd'hui, ce qui permet de replacer ces œuvres dans l'actualité politique de leur temps.

3 Anne Salamon (Les Neuf Preux: des Hommes Illustres?, pp. 84-88) remarque dans trois textes de la fin du $\mathrm{xV}^{\mathrm{e}}$ siècle (l'Histoire des Neuf Preux et des Neuf Preues de Sébastien Mamerot, le Triumphe des Neuf Preux et l'Histoire des preux princes) une évolution de la thématique des neuf preux de simple élément narratif à sujet d'œuvres autonomes. Cette variation pourrait s'expliquer par la forte influence stylistique que le motif des hommes Illustres eut à cette époque.

4 ANNE SCHOYSMAN, "Mimésis", X: les variantes du réalisme "créaturel", dans «Moderna», XI, 1-2, 2009, Erich Auerbach, a cura di Mario Domenichelli e Maria Luisa meneGHetTI, pp. 153-164.

6 Après avoir resitué le chapitre consacré au Reconfort de Madame de Fresne d'Antoine de La Sale dans le plan d'ensemble de Mimésis, A.S. rappelle le double jugement 
d'Auerbach - un jugement fortement négatif sur le plan de la langue, positif sur le contraste établi entre le réalisme du quotidien et le tragique qui s'y mêle - sur une œuvre qui demeure aujourd'hui encore peu connue. L'adjectif «créaturel» (le néologisme est introduit par le critique allemand dans ce même chapitre X) définit le réalisme bourguignon de la fin du Moyen Âge, un réalisme encore «étroit et médiéval» si on le compare à celui d'un Dante ou d'un Boccace, mais un réalisme qui introduit et approfondit pour la première fois dans la littérature française la dimension du tragique de la vie. 